\title{
Molecular identification of insecticide degradation by gut bacteria isolated from Helicoverpa armigera of Cotton plants
}

\author{
Madhusudan S* \\ Department of Biotechnology, Maharani Cluster University, Bangalore- 560001 (Karnataka), \\ India \\ S.K. Jalali \\ Division of Molecular Entomology, National Bureau of Agriculturally Important Insect Resources \\ (ICAR), Bangalore - 560043 (Karnataka), India \\ Sibi G \\ Department of Biotechnology, Indian Academy Degree College-Autonomous, Bangalore- 560043 \\ (Karnataka), India \\ ${ }^{*}$ Corresponding author. Email: mailmadhubiotech@gmail.com
}

\section{How to Cite}

Madhusudan, S. et al. (2021). Molecular identification of insecticide degradation by gut bacteria isolated from Helicoverpa armigera of Cotton plants. Journal of Applied and Natural Science, 13(2), 641 - 653. https://doi.org/10.31018/jans.v13i2.2678

\begin{abstract}
The cotton bollworm Helicoverpa armigera occurs as a major pest in many economically important crops, including cotton, pigeon pea, chickpea, pea, cowpea, sunflower, tomato, sorghum, pearl millet and other crops. Intestinal microorganisms play important role in the degradation of diet components of insects. In order to know the role of gut bacteria in insecticide resistance five insecticides Chlorpyriphos (20\% EC), Cypermethrin (25\% EC), Malathion (50\% EC), Quinalphos (25\% EC), Triazophos $(40 \% \mathrm{EC})$, were selected for the insecticide degradation studies. All the bacterial isolates from the gut of lab and field populations of $\mathrm{H}$. armigera were identified using 16S rRNA gene-based identification and tested for their growth on minimal salt medium (MSM) along with the selected insecticides. A total of 11 bacterial isolates were tested and among them, isolate CL4 (Rhodococcus sp.) was found to grow on minimal salt medium (MSM) and with chlorpyriphos and isolate CL2 (Enterococcus casseliflavus) was able to grow in MSM with chloropyriphos $\left(\mathrm{C}_{22} \mathrm{H}_{19} \mathrm{C}_{12} \mathrm{NO}_{3}\right)$ and malathion $\left(\mathrm{C}_{10} \mathrm{H}_{19} \mathrm{O}_{6} \mathrm{PS}_{2}\right)$ and no growth was seen in MSM without insecticide (control). Gas Chromatography analysis of the positive bacterial isolate cultures in MSM showed that the isolate CL4 (Rhodococcus sp.) was able to utilize $43.9 \%$ of chlorpyriphos and isolate CL2 (E.casseliflavus) was able to utilize $26 \%$ of chlorpyriphos and $57.1 \%$ of malathion in MSM broth cultures with comparison with the respective control cultures. Findings of the current work suggested that gut bacteria in the field populations of $H$. armigera plays a role in insecticide resistance.
\end{abstract}

Keywords: Cotton plants, Gut bacteria, Helicoverpa armigera, Insecticide degradation, Molecular identification

\section{INTRODUCTION}

Old-World bollworm (Helicoverpa armigera) has attained the status of national pest owing to its devastative nature on commercial crops in India. The cotton bollworm $H$. armigera occurs as a major pest in many economically important crops, including cotton, pigeon pea, chickpea, pea, cowpea, sunflower, tomato, sorghum, pearl millet and other crops. The cotton grown in over $5 \%$ of the total cultivated area has consumed more than $55 \%$ of the total amount of pesticide used in India (Kranthi et al. 2001)

A robust complement of prokaryotes is harbored in in- sects' alimentary canals, facilitating nutrient availability, utilization, and detoxification of environmental toxins. Intestinal microorganisms play important role in the degradation of diet components of insects (Hayashi et al., 2007). However, the indigenous gut bacteria also play a role in withstanding and colonization of the gut by non-indigenous species including pathogens (Dillon and Dillon, 2004). Precious little is known about the microbial community inhabiting the guts of various higher organisms, though it is acknowledged that microbes play an important role in metabolism, growth, development and protection of their host. Lepidoptera species feed on plants and the biomass digestion is 
aided by gut associated microbes (Rajagopal et al., 2002). However, the diversity of insect gut microflora is not revealed well and understanding the role of those microflora during the insect growth and development would help in effective pest management. $H$. armigera harbors diverse bacterial communities in its gut regions (Dar et al., 2021). Recently, Bacillus sp were isolated from gut region of $H$. armigera by culture dependent methods (Shinde et al., 2019).

Detoxification of the environmental pollutants, pesticide detoxification in soil and other ecosystems by microorganisms have been reported earlier. Biological removal of chemo pollutants becomes the method of choice since microorganisms can use a variety of xenobiotic compounds including pesticide for their growth and mineralize and detoxify those (Kanekar et al., 2004). Microbial degradation, metabolites of degradation, enzymatic degradation and genetic basis of degradation of widely used organo phosphorous insecticides, like parathion, methyl parathion, malathion, monocrotophos and dimethoate are studied extensively. Insect gut microbes, especially insecticide-resistant pest, might play a role in detoxifying the insecticides. Microbial degradation of organo phosphorous insecticides have been reported in soil and consortia. Pure culture studies have shown cleavage of molecules and formation of different metabolites such as p-nitrophenol, diethylthiophosphoric acid, p-aminophenol, dimethyl phosphate.Verma et al. (2006) reported the degradation of endosulfan by a Rhodococcus strain isolated from gut of earthworm. Bacteria belonging to genera Bacilli, Proteus, Micrococcus, Pseudomonas and Klebsiella isolated from the gut of rice hispa, Dicladispa armigera (Olivier) were shown resistant to $1000 \mathrm{ppm}$ endosulfan and to some extent chloropyriphos and quinalphos (Thakur et al., 2005). Carboxylesterases isolated from $H$. armigera play a role in pyrethroids detoxification (Bai et al., 2019). H. armigera larva fed with laccasses from Yersinia enterocolitica showed significant expression of enzymes and proteins for xenobiotic degradation (Ahlawat et al., 2020).

Chemical insecticides are the most widely released xenobiotics by humankind into the environment, resulting in very high contamination of food and water resources with these compounds. Many insects and bacteria have developed resistance to these compounds by evolving enzymes to metabolize these xenobiotics. Indepth research is required to identify potential candidates with respect to gut microbes in the degradation of insecticides/xenobiotics. This study was carried out to determine the influence of gut microflora isolated from $H$. armigera in insecticidal resistance.

\section{MATERIALS AND METHODS}

\section{Collection of field larvae}

The culture of the $H$. armigera was initiated by collect- ing about 100 - 150 larvae on cotton (Gossypium hirsutum L., Kanchana variety) from the farmers' fields in Vikarabad (Andhra Pradesh-Lat-17019'60N; Lon$77^{\circ} 55^{\prime} 0 \mathrm{E}$ ), where insecticides were used frequently. On cotton, efforts were made to collect the larvae from non -Bt cotton, which was sprayed both for lepidopteran and sucking pests. Fourth- and fifth-instar larvae were collected in the plastic container with an artificial diet and brought to the laboratory and were used for the study. The insecticide use pattern was recorded at each place as per the protocols of the National Bureau of Agriculturally Important Resources, ICAR, Bangalore.

\section{Rearing of field and laboratory populations of $\boldsymbol{H}$. armigera}

The collected larvae were brought to the National Bureau of Agriculturally Important Insects (NBAII) laboratory, Bangalore. The larvae were transferred onto a freshly prepared semi synthetic diet (Nagarkatti and Satyaprakash, 1974). After pupation, the pupae were collected, surface sterilized in sodium hypochlorite $(0.1 \%)$ and washed in distilled water. The washed pupae were air-dried at room temperature and kept in plastic jars for the emergence of moth. From the emerged moths, 25 pairs were transferred to each oviposition cage lined with muslin cloth and covered with a black cotton cloth. Two balls of absorbent cotton, one with water and another one with $50 \%$ honey solution, were provided in the oviposition cage. The eggs were collected from the cages every $24 \mathrm{~h}$ were washed in sodium hypochlorite $(0.1 \%)$ and formaldehyde $(1 \%)$ solution, filtered through a black cloth and tagged onto the plastic container (7 cm dia., $4 \mathrm{~cm}$ height) for hatching at $27 \pm 2^{\circ} \mathrm{C}$ and $70 \% \mathrm{RH}$.

The newly hatched neonates were transferred to 128 well diet trays containing solidified diet at 1 larva well $^{-1}$ using a fine hairbrush and were covered with pull-npeel tabs. Both diet trays and neonates transfer were carried out on a laminar airflow clean bench followed by maintenance in a BOD incubator maintained at $27 \pm 2^{\circ} \mathrm{C}$ and 14:10 $\mathrm{h}$ light-dark. Fifty pupae of the susceptible strain of the $H$. armigera were also obtained from the Mass Production Unit of NBAIR, Bangalore, where it is reared on semi-synthetic diet for 10 years without replacing or adding any field population, hence was considered true susceptible populations. These pupae were also reared till the emergence of the adults and thus, the culture was further multiplied to be used in the bioassay studies with the same method as that of the field collected $H$. armigera. A homogenous stock of fifth instar larvae (10-11 days old) was for isolating the gut bacteria.

Isolation of gut bacteria from $\boldsymbol{H}$. armigera

For the isolation of gut bacteria, ten larvae of $\mathrm{H}$. armi- 
gera were immobilized in chloroform and sterilized in sodium hypochlorite $(0.1 \%)$ and ethanol $(70 \%)$ solution for 5 seconds to remove the contaminants (Gebbardi et al., 2001). The sterilized larvae were dissected under aseptic conditions in a Laminar air flow hood to remove the entire gut. The gut was placed in a micro tube containing $500 \mu \mathrm{l}$ of sterile peptone water, crushed mechanically and vortexed thoroughly. A hundred $\mu$ of the gut homogenate was placed on sterile nutrient agar and nutrient glucose agar plates in replicates and incubated at $30^{\circ} \mathrm{C}$ for $48 \mathrm{~h}$. The colonies obtained after $48 \mathrm{~h}$ incubation in the plates were further screened for colony morphology.

\section{Bacterial DNA isolation}

Bacterial genomic DNA was isolated as per the standard protocol (Hoffman and Winston 1987). A single colony from each of the bacterial cultures was inoculated in nutrient broth and grown for $48 \mathrm{~h}$ at $30^{\circ} \mathrm{C}$. The cells were harvested by centrifugation and added with $100 \mu \mathrm{l}$ of lysozyme followed by incubation at room temperature for 30 mins to disrupt the cell membrane. The cells were lysed by the addition of lysis buffer $(70 \mu \mathrm{l})$ containing guanidium isothiocyanate, SDS and tris-EDTA. The contents were mixed by inverting and $700 \mu \mathrm{l}$ of isopropanol was added from the top. The two layers were gently mixed until the DNA strands were visible and the addition of ice cold ethanol precipitated the extracted DNA. The DNA was resuspended in $100 \mu \mathrm{l}$ of TE buffer and the quality of DNA was checked in agarose gel electrophoresis. The purified genomic DNA was used as template for 16S rRNA gene amplification.

\section{Oligonucleotide primers}

16S rRNA gene primers were procured from Aristogene Biosciences ( $P$ ) Ltd, Bangalore. The oligonucleotides were reconstituted to $100 \mathrm{ng} / \mu \mathrm{l}$ stocks in sterile TE buffer. The primers were used at a working concentration $100 \mathrm{ng} / \mu \mathrm{l}$ in sterile filtered distilled water. The sequences of the primers were as follows

Forward primer - 5'-ACTCCTACGGGAGGCAGCAG-3' Reverse primer - 5'-ATTACCGCGGCTGCTGG-3'

\section{Amplification of 16S rRNA gene by PCR}

Gradient PCR was used to determine the optimum annealing temperature. The reaction mixture contained $100 \mathrm{ng}$ of the extracted DNA, 1X PCR assay buffer (250 mM Tris- $\mathrm{HCl}, 10 \mathrm{mM} \mathrm{KCl}, 1.5 \mathrm{mM} \mathrm{MgCl} 2$ ), 100 $\mathrm{mM}$ dNTP's, $100 \mathrm{ng} / \mu \mathrm{L}$ each of forward and reversed primers, 1 unit of Taq DNA polymerase (Sigma Aldrich, India). PCR performed with forward and reverse primers involved an initial denaturation for 2 mins at $94^{\circ} \mathrm{C}$, followed by 30 cycles of $94^{\circ} \mathrm{C}$ denaturation for $1 \mathrm{~min}$, $58^{\circ} \mathrm{C}$ for annealing for $30 \mathrm{~s}$ and extension at $72^{\circ} \mathrm{C}$ for 1 $\min 30 \mathrm{~s}$. Finally, the reactions were healed at $72^{\circ} \mathrm{C}$ for 5 min. Specific and optimum amplification of the gene was seen at $58{ }^{\circ} \mathrm{C}$ of annealing temperature. Subsequently, the gene was amplified at $58^{\circ} \mathrm{C}$ and the amplified PCR product $(1.5 \mathrm{~Kb})$ was purified from low melting agarose gel as per the standard protocols (Sambrook et al. 2001) for further sequencing at Aristogene Biosciences (P) Ltd, Bangalore. The obtained sequences were analyzed through BLAST search and the bacterial species were identified.

\section{Media preparation for insecticide degradation studies}

The bacterial colonies isolated were tested for the selected eight commercial insecticides against chlorpyriphos, cypermethrin, malathion, quinalphos and triazophos, the most commonly used insecticides against $H$. armigera at a concentration range of $0.2,0.4,0.6,0.8$ and $1.0 \mathrm{ml} / \mathrm{l}$, respectively. Initial studies were carried out on the bacterial isolates for their growth on Minimal Salt Medium (MSM) with and without insecticides. The composition of MSM included $\mathrm{KH}_{2} \mathrm{PO}_{4} 1.0 \mathrm{~g}, \mathrm{~K}_{2} \mathrm{HPO}_{4}$ $1.0 \mathrm{~g}, \mathrm{NH}_{4} \mathrm{NO}_{3} 1.0 \mathrm{~g}, \mathrm{MgSO}_{4} .7 \mathrm{H}_{2} \mathrm{O} 0.2 \mathrm{~g}, \mathrm{CaCO}_{3} 0.02$ $\mathrm{g}, \mathrm{FeSO}_{4} 0.01 \mathrm{~g}$ in $1 \mathrm{~L}$ of distilled water $(\mathrm{pH} \mathrm{6.5)}$. The isolated bacteria from the guts of lab and field larval populations $H$. armigera were purified from nutrient agar plated in duplicates and incubated at room temperature $\left(28 \pm 1^{\circ} \mathrm{C}\right)$ for $48 \mathrm{~h}$. Isolated colonies were picked and streaked onto nutrient agar plates to obtain pure cultures. All the pure bacterial isolates were tested for their growth on MSM with and without insecticides. Different concentration of selected insecticides as mentioned above was added into sterile MSM (agarbased) and poured into Petri plates in Laminar airflow. The Petri dishes were labelled according to the concentration of selected insecticides after solidification. Similarly,MSM plates were also prepared without insecticides. All the bacterial isolates were streaked onto these plates in aseptic conditions and were incubated at room temperature $\left(28 \pm 1^{\circ} \mathrm{C}\right)$ for $48 \mathrm{~h}$. Growth of the bacterial isolates on all the plates were recorded after $48 \mathrm{~h}$. Bacterial isolates growing in a particular concentration of insecticide was isolated and subcultured on nutrient agar to obtain a pure culture. Positive cultures for growth on MSM with insecticide $(0.2 \mathrm{ml} / \mathrm{l})$ were further used for degradation studies. A series of $250 \mathrm{ml}$ flask containing $50 \mathrm{ml}$ of MSM (broth) supplemented with above mentioned insecticides at $0.2 \mathrm{ml} / \mathrm{l}$ concentration was incubated separately with $1 \mathrm{ml}$ overnight grown positive cultures and incubated on a shaker 200 rpm at $30^{\circ} \mathrm{C}$ for 10 days. Controls for each bacterium were maintained without insecticides and positive control of MSM with insecticides alone was also maintained. After 10 days incubation CFU count was recorded on nutrient agar plates. The cell mass in MSM with and without insecticides was separated by centrifugation at $8000 \mathrm{xg}$ for $10 \mathrm{~min}$ and supernatant of $50 \mathrm{ml}$ was collected separately in the fresh tubes. The super- 
natant was further analyzed in GC to detect the concentration of insecticides at the GC-MS facility available at Bangalore Test House, Bangalore.

\section{Gas Chromatography analysis of minimal salt} media with insecticides

The samples containing insecticide and without insecticide were extracted with methylene chloride solvent, initially using $100 \mathrm{ml}$ solution initially. Later the volume of $50 \mathrm{ml}$ twice was used to partition the sample. The pooled extract was collected in the separate round bottom flask after passing through anhydrous sodium sulphate. The content was evaporated to dryness using a vacuum rotary evaporator and a volume of $2 \mathrm{ml}$ of acetone was added to the residue. One $\mu \mathrm{l}$ of this solution was injected into GC-ECD.

\section{GC Conditions}

Instrument: Agilent 6890N GC with 975 inert MSD

Software: MSD chemstation D.02.00.275 with NIST Library Ver.2.0d

Column:DB-35 MSI, $30 \mathrm{~m} \times 0.25 \mathrm{~mm} \times 250$ micron

Inlet Temperature: $250^{\circ} \mathrm{C}$

Injection Mode: Split less

Injection Volume: $1 \mu \mathrm{l}$

Carrier gas flow: Helium (constant flow) $1.0 \mathrm{ml} / \mathrm{min}$

Oven program: $70^{\circ} \mathrm{C}$ for $2 \mathrm{~min}$, @ $4^{\circ} \mathrm{C} / \mathrm{min}, 160^{\circ} \mathrm{C}$ for 5 $\min , 4^{\circ} \mathrm{C} / \mathrm{min}$

Final temp.: $295^{\circ} \mathrm{C}$ for $10 \mathrm{~min}$.

Transfer line temp.: $280^{\circ} \mathrm{C}$

The concentration of insecticides in MSM broth cultures was calculated using the formula

Sample peak area $X$ Std. Conc. $(\mu \mathrm{g} / \mathrm{ml}) \mathrm{X}$ dilution

\section{Standard peak area}

Working std. conc. $(\mu \mathrm{g} / \mathrm{ml}): \quad 1.2 \mu \mathrm{g} / \mathrm{ml}$

Dilution (ml): $13 \mu \mathrm{l}$ of insecticide formulation was diluted to $25 \mathrm{ml}$ using acetone and $1.0 \mu \mathrm{l}$ was injected into GC-ECD instrument.

\section{RESULTS AND DISCUSSION}

Isolation of gut bacterial flora from the insecticide resistance larval populations collected from cotton and susceptible lab populations of $\boldsymbol{H}$. armigera

Gut bacteria isolated from the gut of insecticideresistant fourth and fifth instar larvae of $H$. armigera collected from the cotton fields of Vikarabad, Andhra Pradesh were coded as CL1, CL2, CL3, CL4, CL5, CL6 and CL7. Gram staining of the bacterial isolates showed that isolates CL1, CL3 were Gram +ve rods, isolates CL2, CL4, CL6 were Gram +ve cocci and isolates CL5, CL7 were Gram -ve rods. Gut bacteria was isolated from the gut of susceptible fourth and fifth in- star larvae of $\mathrm{H}$. armigera collected from the mass production unit of NBAll, Bangalore was coded as HL1, HL2, HL3, HL4, HL5 and HL6. Gram staining of the bacterial isolates showed that the isolates HL1, HL3, HL5, HL6 were Gram - ve rods and isolates HL2, HL4 were Gram +ve rods.

Isolation of DNA and 16s rRNA PCR amplification of gut bacteria of insecticide-resistant and susceptible larvae of $\boldsymbol{H}$. armigera

DNA was isolated from eleven bacterial isolates from the gut of insecticide-resistant field larvae of $H$. Armigera. The presence of genomic DNA from all the seven isolates was confirmed on a $0.8 \%$ agarose gel stained with ethidium bromide (Fig. 1). An intense single band was seen in all seven wells along with the DNA marker. The extracted DNA was used as a template for amplification of 16S rRNA gene. The primers selected were specific. Initial standardisation by gradient PCR has facilitated the specific amplification as observed by high intense band. The optimum annealing temperature was found to be $58^{\circ} \mathrm{C}$ and an intense single band of size approximately $1.5 \mathrm{~kb}$ was visible on $1 \%$ agarose gel stained with ethidium bromide (Fig. 2) in all the seven wells. Similarly, DNA was isolated from six bacterial isolates from the gut of susceptible larvae of $\mathrm{H}$. armigera. The presence of genomic DNA from all the 6 isolates was confirmed on a $0.8 \%$ agarose gel stained with ethidium bromide (Fig. 3). An intense single band was seen in all six wells along with the DNA marker. The extracted DNA was used as the template for amplification of 16S rRNA gene. The primers selected were specific. The optimum annealing temperature was found to be $58^{\circ} \mathrm{C}$. An intense single band of size approximately $1.5 \mathrm{~kb}$ was visible on $1 \%$ agarose gel stained with ethidium bromide (Fig. 4) in all 6 wells.

Sequencing and sequence analysis of PCR amplified 16S rRNA gene of the eleven gut bacterial isolates

The partial sequence obtained from all the seven isolates ranged from $677,660,478,459,642,514.559 \mathrm{bp}$ respectively in length and were analysed in BLASTn (www.ncbi.nlm.nih.gov) and the bacterial genera and species were determined. The partial $16 \mathrm{~S}$ rRNAs sequence and the determined bacterial sp. along with the accession number (CL1-CL7) are shown in Table 1. The max identity of the sequence was $99-100 \%$. The nucleotide sequences of seven isolates are submitted to NCBI-Gen Bank and the accession numbers were obtaind. The determined bacterial communities were found to be CL1-Bacillus pumulis, CL2-Enterococcus casseliflavus, CL3-Bacillus subtilis, CL4-Rhodococcus sp., CL5-Pseudomonas sp., CL6-Staphylococcus sp., CL7-Pseudomonas aeruginosa.

The partial sequence obtained from all the 6 isolates 


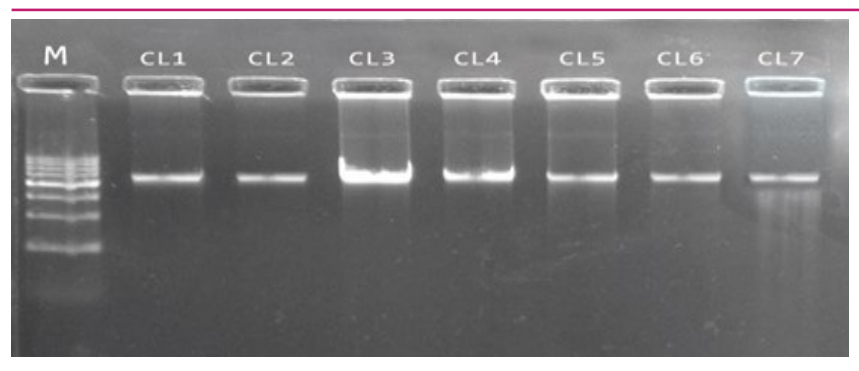

Fig 1. Agarose gel electrophoresis of genomic DNA from seven bacterial isolates from gut of $\mathrm{H}$. armigera from cotton crop. M- Standard DNA Marker, CL1 - CL7 - Genomic DNA of the bacterial isolates.

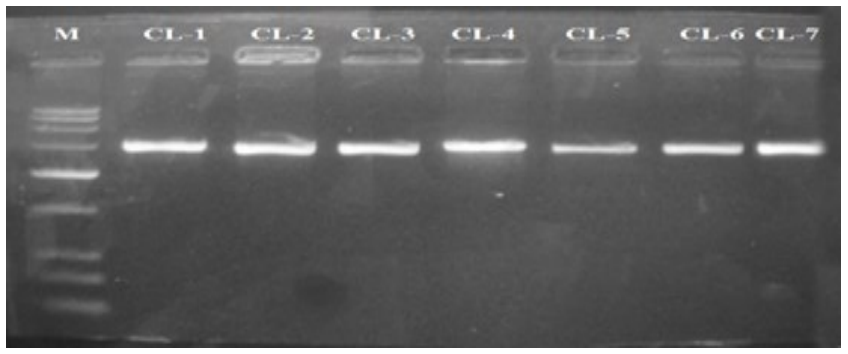

Fig. 2. Agarose gel electrophoresis of $16 S$ rRNA PCR amplicon from seven bacterial isolates from gut of $\mathrm{H}$. armigera from cotton crop. M- 0.1-3 kb Low range marker: sizes- 100bp, 200bp, 300bp, 600bp, 1kb, 1.5kb, $2 \mathrm{~kb}$, 2.5kb, $3 \mathrm{~kb})$., CL1 - CL7 - 16S rRNA PCR amplicon of the bacterial isolates.

from the gut of the susceptible larvae of $H$. armigera ranged from $664,861,779,623,541,693 \mathrm{bp}$. in length The partial $16 \mathrm{~S}$ rRNAs sequence and the determined bacterial sp. along with the accession number (HL1HL6) areshown in Table 2. The max identity of the sequence was $99-100 \%$. The nucleotide sequences of 6 isolates were submitted to NCBI-Gen Bank and the accession numbers were obtained. The determined bacterial communities were found to be HL1-Proteus vulgaris, HL2-Cellulosimicrobium cellulans, HL3Klebsiella oxytoca, HL4-Bacillus subtilis, HL5 Stenotrophomonas maltophilia, and HL6-Pseudomonas sp.

Insecticide degradation studies by the gut microbial isolates from susceptible lab and field populations of $\boldsymbol{H}$. armigera

All the five insecticides were selected for the insecticide degradation studies. Growth of the bacterial isolates recorded after 7 days of incubation at $30^{\circ} \mathrm{Cis}$ shown in Table 3. Among a total of 11 bacterial isolates tested, isolate CL4 (Rhodococcussp.) was found to grow on minimal salt medium (MSM) and with chlorpyriphos and isolate CL2 (Enterococcus casseliflavus) was able to grow in MSM with chloropyriphos and malathion and no growth was seen in MSM without insecticide (control). The growth of isolates CL4 and CL2 on MSM without insecticide (control) and with insecticides is shown in
Plate 1. Bacterial isolates CL4 and CL2 were further grown in MSM broth without and with insecticides and incubated in shaker at $30^{\circ} \mathrm{C}$ for 7 days, after incubation $0.1 \mathrm{ml}$ of the culture was plated on to sterile nutrient agar plates and were incubated at $30^{\circ} \mathrm{C}$ for $48 \mathrm{~h}$ and the number of CFU was calculated along with control and data is shown in Table 4 GC graph results have been shown for MSM with insecticides, MSM with isolate CL4 without insecticide and with chlorpyiphos and MSM with isolate CL2 without insecticides and with chlorpyriphos and malathion in Figure 5, 6, and 7 respectively. The concentration of the insecticides in the MSM broth cultures along with the control are shown in Table 5. GC graph analysis showed that there was decrease in the concentrations of the insecticides in MSM broth cultures with insecticides when compared to that of MSM broth cultures without insecticides. The isolate CL4 (Rhodococcus sp.) was able to utilize $43.9 \%$ of chlorpyriphos and isolate CL2 (Enterococcus casseliflavus) was able to utilize $26 \%$ of chlorpyriphos and $57.1 \%$ of malathion in MSM broth cultures with comparison with the respective control cultures. Findings of the current results suggested that gut bacteria in the field populations of $H$. armigera is having a role in insecticide resistance.

Broderick et al., (2004) described the isolation and

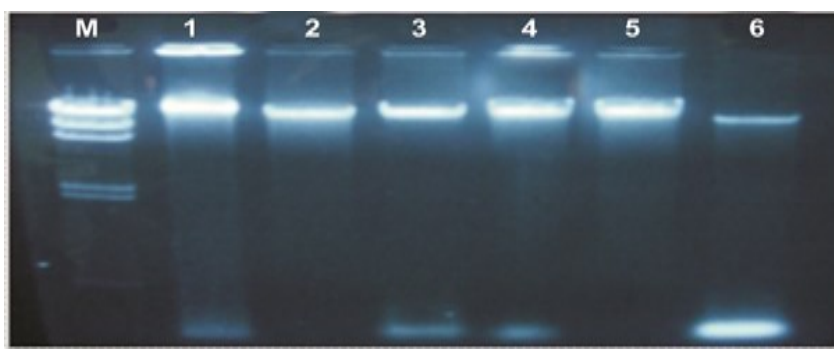

Fig. 3. Agarose gel electrophoresis of genomic DNA from six bacterial isolates from the gut of larvae of laboratory populations of $H$. armigera. Lane $M-M a r k e r-L a m b d a /$ HindIII digest (sizes-23130, 9416, 6557, 4361, 2322, 2027, 564). Lane $1-6$ - Genomic DNA from 6 bacterial isolates.

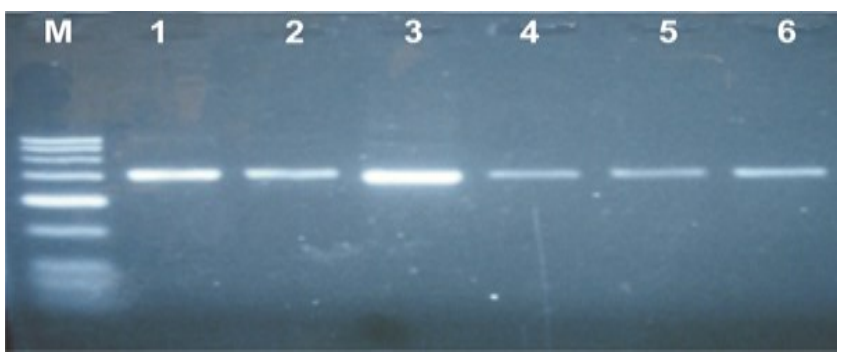

Fig. 4. Agarose gel electrophoresis of $16 S$ rRNA PCR amplicon from six bacteria isolates from gut of the larvae of laboratory populations of $\mathrm{H}$. armigera. Lane M- Marker 0.1-3 kb Low range marker: sizes- 100bp, 200bp, 300bp, 600bp, 1kb, 1.5kb, 2 kb, 2.5kb, 3 kb)., Lane - HL1 - HL6 16S rRNA PCR amplicon of the bacterial isolates, $1=H L 1$, 2=HL2, 3=HL3, 4=HL4, 5=HL5, $6=H L 6$. 
Table 1. Partial 16S rRNA sequence and identified bacterial species with GenBank accession number of the seven bacterial isolates from the gut of insecticide resistance field larval populations of $H$. armigera collected from cotton crop.

\begin{tabular}{llll} 
Isolate Partial 16S rRNA gene sequence & Size (bp) $\begin{array}{l}\text { Identified Bacteria } \\
\text { By BLASTn }\end{array}$ & $\begin{array}{l}\text { GenBank } \\
\text { Accession } \\
\text { Number }\end{array}$ \\
\hline
\end{tabular}

GTGCATTGCGGGTGCTATACATGCAAGTCGAGCGGACAGAAGGGAGCTTGCTCCCGGGTGTTAGCGGCGGACGGGT GAGTAACACGTGGGTAACCTGCCTGTAAGACTGGGATAACTCC GGGAAACCGGAGCTAATACCGGATAGTTCCTTGAACCGCATGG TTCAAGGATGAAAGACGGTTTCGGCTGTCACTTACAGATGGACC CGCGGCGCATTAGCTAGTTGGTGAGGTAACGGCTCACCAAGGC GACGATGCGTAGCCGACCTGAGAGGGTGATCGGCCACACTGG

CL1 GACTGAGACACGGCCCAGACTCCTACGGGAGGCAGCAGTAGG GAATCTTCCGCAATGGACGAAAGTCTGACGGAGCAACGCCGCG TGAGTGATGAAGGTTTTCGGATCGTAAAGCTCTGTTGTTAGGGA AGAACAAGTGCAAGAGTAGCTGCTTGCACCTTGACGGTACCTAA CCAGAAAGCCACGGCTAACTACGTGCCAGCAGCCGCGGTAATA CGTAGGTGGCAAGCGTTGTCCGGAATTATTGGGCGTAAAGGGC TCGCAGGCGGTTTCTTAAGTCTGATGTGAAAGCCCCCGGCTCAA CCGGGGAGGGTCATTGGAAACTGGAAACTTGATTGCAGAAGAG GAGAGTGTAATTCCACGTGTAGCGGTGAAATGCGAAAAAA

\section{$677 \quad$ Bacillus pumulis}

HQ651050

GATTATGGCTCAGGACGAACGCTGGCGGCGTGCGTAATACATGCAAG TCGAACGCTTTTTCTTTCACCGGAGCNTGCTCCANCGNAAGAAAAAGAGTGGCGAACGGGTGAGT AACACGTGGGTAACCTGCCCATCAGAAGGGGATAACACTTGGA AACAGGTGCTAATACCGTATAACACTATTTTCCGCATGGAAGAA AGTTGAAAGGCGCTTTTGCGTCACTGATGGATGGACCCGCGGT GCATTAGCTAGTTGGTGAGGTAACGGCTCACCAAGGCAACGAT

CL2 GCATAGCCGACCTGAGAGGGTGATCGGCCACACTGGGACTGAG ACACGGCCCAGACTCCTACGGGAGGCAGCAGTAGGGAATCTTC GGCAATGGACGAAAGTCTGACCGAGCAACGCCGCGTGAGTGAA GAAGGTTTTCGGATCGTAAAACTCTGTTGTTAGAGAAGAACAAG GATGAGAGTAAAATGTTCATCCCTTGACGGTATCTAACCAGAAA GCCACGGCTAACTACGTGCCAGCAGCCGCGGTAATACGTAGGT GGCAAGCGTTGTCCGGATTTATTGGGCGTAAAGCGAGCGCAGG CGGTATCTTAAGTCTGATGTGAAAGCCCCCGGCTCAACCGGGG AGGGTCATTGGAAACTGGGAGACTTGAGT

Enterococcus casseliflavus

HQ651051

TGCAGTCGAGCGGACAGATGGGAGCTT-

GCTCCCTGATGTTAGCGGCGGACGGGTGAGTAACACGTGGGTA ACCTGCCTGTAAGACTGGGATAACTCCGGGAAACCGGGGCTAA TACCGGATGGTTGTTTGAACCGCATGGTTCAAACATAAAAGGTG GCTTCGGCTACCACTTACAGATGGACCCGCGGCGCATTAGCTA

CL3 GTTGGTGAGGTAACGGCTCACCAAGGCAACGATGCGTAGCCGA CCTGAGAGGGTGATCGGCCACACTGGGACTGAGACACGGCCC AGACTCCTACGGGAGGCAGCAGTAGGGAATCTTCCGCAATGGA CGAAAGTCTGACGGAGCAACGCCGCGTGAGTGATGAAGGTTTT CGGATCGTAAAGCTCTGTTGTTAGGGAAGAACAAGTACCGTTCG AATAGGGCGGTACCTTGACGGTACCTAACCAGAAAGCCACGGC TAACTACGTGCCAGCAGCCG

GGGCCCGTGGGGGAGGACTACACATGCAAGTCGAGCGGATGAAGGGAGCTTGCTCCTGGATTCAGCGGCGGACGGGTGA GTAATGCCTAGGAATCTGCCTGGTAGTGGGGGATAACGTCCGG AAACGGGCGCTAATACCGCATACGTCCTGAGGGAGAAAGTGGG GGATCTTCGGACCTCACGCTATCAGATGAGCCTAGGTCGGATTA GCTAGTTGGTGGGGTAAAGGCCTACCAAGGCGACGATCCGTAA CTGGTCTGAGAGGATGATCAGTCACACTGGAACTGAGACACGG TCCAGACTCCTACGGGAGGCAGCAGTGGGGAATATTGGACAAT GGGCGAAAGCCTGATCCAGCCATGCCGCGTGTGTGAAGAAGGT CTTCGGATTGTAAAGCACTTTAAGTTGGGAGGAAGGGCAGTAAG TTAATACCTTGCTGTTTTGACGTTACCAACAGAATAAGCACCGG CTAACTTCGTGCCAGCAGCCGCGGTAATACGAAGGGTGCAAGC GTTAATCGGAATTACTGGGCGTAAAGCGCGCGTAGGTGGTTCA GCAAGTTGGATGTGAAATCCCCGGGCTCAACCTGGGAACTGCA TCCCAAAACTACTGAGCTAGAGTACGGTAGAGGGTGGTGGAAA 
Table.1. Contd......

GTCTGCGGCATGCTATACATGCAGTCGAGCGAACAGACGAGGAGCTTGCTCCTTTGACGTTAGCGGCGGACGGGTGAGTAACACGTAGGTAACCT ACCTATAAGACTGGGATAACTTCGGGAAACCGGAGCTAATACCGGATAA TATTTCGAACCGCATGGTTCGATAGTGAAAGATGGCTTTGCTATCACTTA TAGATGGACCTGCGCCGTATTAGCTAGTTGGTAAGGTAACGGCTTACCA AGGCAACGATACGTAGCCGACCTGAGAGGGTGATCGGCCACACTGGAA CTGAGACACGGTCCAGACTCCTACGGGAGGCAGCAGTAGGGAATCTTC CGCAATGGGCGAAAGCCTGACGGAGCAACGCCGCGTGAGTGATGAAG GTCTTCGGATCGTAAAACTCTGTTATTAGGGAAGAACAAACGTGTAAGTA ACTGTGCACGTCTTGACGGTACCTAATCAGAAAGCCACGGCTAACTACG TGCCAGCAGCCGCGGTAATACGTAGGTGG
CTGTTCTGTCGGCAGCTAGACATGCAAGTCGAGCGGATGAAGGGAGCTTGCTCCTGGATTCAGCGGCGGACGGGTGAGTAATG CCTAGGAATCTGCCTGGTAGTGGGGGATAACGTCCGGAAACGGGCGCT AATACCGCATACGTCCTGAGGGAGAAAGTGGGGGATCTTCGGACCTCA CGCTATCAGATGAGCCTAGGTCGGATTAGCTAGTTGGTGGGGTAAAGG CCTACCAAGGCGACGATCCGTAACTGGTCTGAGAGGATGATCAGTCACA CTGGAACTGAGACACGGTCCAGACTCCTACGGGAGGCAGCAGTGGGGA ATATTGGACAATGGGCGAAGCCTTGATCCAGCCATGCCGCGTGTGTGAA GAAGTCTTCGGATTGTAAACACTTTAAGTTGGGAGAAGGCAGAAGTTAA TACCTTGGTTGTTTTGACGTACCACAGAATAAGCACCGGCTACTTCTGC CGCAGCCGCGTATACCAAGGTGCAGCGTAATTCGAATTACTGGCGTAAG CGCGCGAAGGGTTCACAGGTGGAAGGGAATCCCCGGCTC

\section{Pseudomo-} nas aerugino- HQ651055 sa characterization of gut microflora from Lepidoptera and the present study isolated the gut bacterial flora of $H$. armigera using culture dependent methods.Bacterial isolates were identified using 16S rRNA gene based molecular technique. Different gut bacteria belonging to different genera were isolated and identified from field and lab larval populations of $H$. armigera. Some of the similar gut bacterial isolates have been also isolated from $H$. armigera species in India (Mishra and Tandon, 2003; Priya et al., 2012) in China (Xiang et al., 2006). Actinobacteria, proteobacteria and firmicutes were the dominant bacteria in H.armigera fed on tomato plants (Ranjith et al., 2016). In another study, high prevalence of Gammaproteobacteria followed by Bacilli and Actinobacteria were detected in the $H$. armigera midgut (Paramasiva et al., 2014). Dar et al., (2018) isolated Klebisiella sp, cellulolytic bacteria, from gut of $H$. armigera with xylanase and $\beta$-glucosidase activities. Apart from bacterial population, a novel picorna-like virus, named Helicoverpa armigera Nora virus was found in the gut of $H$. armigera moths and larvae (Yang et al.,
2019). Similarly, Ifla virus was isolated from $H$. armigera by Yuan et al. (2017). Higher animals like humans contain gut bacterial diversity in the range of 1500 2500 . Further, the number of gut bacteria is ten times higher than the total number of host cells and the bacteria have more than ten times the metabolic diversity (Dillon and Dillon, 2004). It was also reported that sexual performance, mating preferences, and oviposition are influenced by the gut microflora (Gavriel et al., 2010; Sharon et al., 2010).

In order to decipher the non-pathogenic interaction between the bacteria and the host, we need first to study the gut flora of the host. In the present study, culture dependent studies showed that the field collected and the lab reared population showed significant differences in bacterial population, which is in agreement with the previous studies (Xiang et al., 2006). Rani et al., (2009) reported that the difference in lab reared and field insects is due to the fact that the laboratory raised insects are exposed to narrower range of food and environmental factors when compared to the field collect-
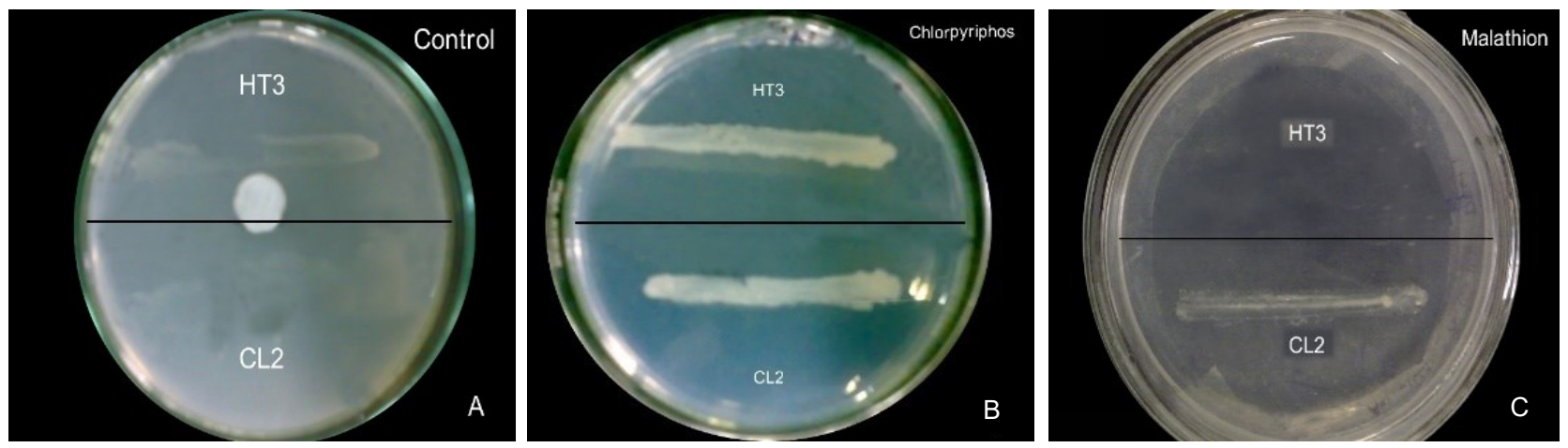

Plate 1. Growth of bacterial isolate CL4 and CL2 on MSM with insecticides. CL4 - Rhodococcus sp. CL2 - Enterococcus casseliflavus. A - Control, B - MSM with Chlorpyriphos, C-MSM with Malathion. 
Madhusudan, S. et al. / J. Appl. \& Nat. Sci. 13(2), 641 - 653 (2021)

Table 2. Partial 16S rRNA sequence and identified bacterial species with GenBank accession number of the six bacterial isolates from the gut of susceptible laboratory larval populations of $H$. armigera.

\begin{tabular}{|c|c|c|c|c|}
\hline Isolate & Partial 16S rRNA gene sequence & Size (bp) & $\begin{array}{c}\text { Identified } \\
\text { Bacteria By } \\
\text { BLASTn }\end{array}$ & $\begin{array}{c}\text { GenBank } \\
\text { Accession } \\
\text { Number }\end{array}$ \\
\hline HL1 & $\begin{array}{l}\text { CATGCAGTCGAGCGGTAACAGGAGAAAGCTTGCTTTCTT- } \\
\text { GCTGACGAGCGGCGGACGGGTGAGTAATGTATGGGGATCTGCC } \\
\text { CGATAGAGGGGGATAACTACTGGAAACGGTGGCTAATACCGCAT } \\
\text { GACGTCTACGGACCAAAGCAGGGGCTCTTCGGACCTTGCGCTAT } \\
\text { CGGATGACCCATATGGGATTAGCTAGTAGGTGAGGTAATGGCT } \\
\text { CACCTAGGCAACGATCTCTAGCTGGTCTGAGAGGATGATCAGCC } \\
\text { ACACTGGGACTGAGACACGGCCCAGACTCCTACGGGAGGCAGC } \\
\text { AGTGGGGAATATTGCACAATGGGCGCAAGCCTGATGCAGCCATG } \\
\text { CCGCGTGTATGAAGAAGGCCTTAGGGTTGTAAAGTACTTTCAGC } \\
\text { GGGGAGGAAGTGATAAATTAATACTTTGTCATTGACGTTAC } \\
\text { CCGCAGAAAAGCACCGGCTAACTCCGTGCCAGCAGCCGCGGT } \\
\text { AATACGGAGGGTGCAAGCGTAATCGGAATACTGGGCGTAAAG } \\
\text { CGCACGCAGGCGGTCAATTAAGTCAGATGTGAAACCCCGAGCT } \\
\text { TAACTTGGGATTGCATCTGAACTGGTTGGCTAGAGTCTTGTAG } \\
\text { AGGGGGTAGAATCCACGTGTAGCGGTGAATGCGTAGAGATG } \\
\text { TGAGGAATAC }\end{array}$ & 664 & $\begin{array}{l}\text { Proteus vulgar- } \\
\text { is }\end{array}$ & JF266593 \\
\hline HL2 & $\begin{array}{l}\text { CATGCAGTCGAACGATGATGCCCAGCTTGCTGGGCGGATTAG- } \\
\text { TGGCGAACGGGTGAGTAACACGTGAGTAACCTGCCCTTGACTTC } \\
\text { GGGATAACTCCGGGAAACCGGGGCTAATACCGGATATGAGCCG } \\
\text { CCTTCGCATGGGGGTGGTTGGAAAGTTTTCGGTCAGGGATGGG } \\
\text { CTCGCGGCCTATCAGCTTGTTGGTGGGGTGATGGCCTACCAAGG } \\
\text { CGACGACGGGTAGCCGGCCTGAGAGGGCGACCGGCCACACTG } \\
\text { GGACTGAGACACGGCCCAGACTCCTACGGGAGGCAGCAGTGGG } \\
\text { GAATATTGCACAATGGGCGAAAGCCTGATGCAGCGACGCCGCGT } \\
\text { GAGGGATGAAGGCCTTCGGGTTGTAAACCTCTTTCAGCAGGGAA } \\
\text { GAAGCGCAAGTGACGGTACCTGCAGAAGAAGCGCCGGCTAACTA } \\
\text { CGTGCCAGCAGCCGCGGTAATACGTAGGGCGCAAGCGTTGTCC } \\
\text { GGATTATTGGGCGTAAAGAGCTCGTAGGCGGTTTGTCGCGTCT } \\
\text { GGTGTGAAACTCGAGGCTCAACCTCGAGCTTGCATCGGGTACG } \\
\text { GGCAGACTAGAGTGCGGTAGGGGAGACTGGATTCCTGGTGTAG } \\
\text { CGGTGGATGCGCAGATATCAGGAGGAACACCGATGGCGAGG } \\
\text { CAGGTCTCTGGGCCGCAATGACGCTGAGGAGCGAAGCATGG } \\
\text { GGAGCGAACAGGATTAGATACCCTGGTTAGTCCATGCCGTAAAC } \\
\text { GTTTGGCACTAGGTGTGGGGGC }\end{array}$ & 861 & $\begin{array}{l}\text { Cellulosimicro- } \\
\text { bium cellulans }\end{array}$ & JF266594 \\
\hline HL3 & 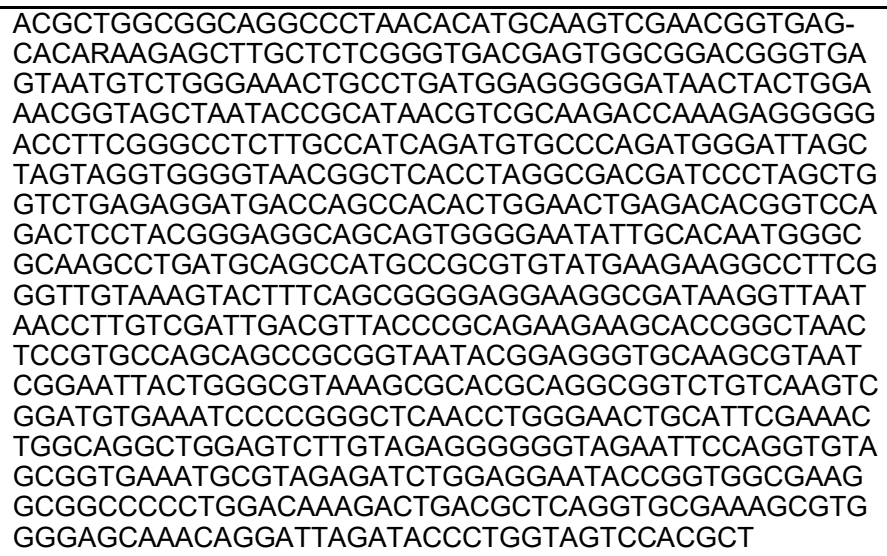 & 779 & $\begin{array}{l}\text { Klebsiella oxy- } \\
\text { toca }\end{array}$ & JF266595 \\
\hline HL4 & $\begin{array}{l}\text { TACATGCAGTCGAGCGGACAGATGGGAGCTT- } \\
\text { GCTCCCTGATGTTAGCGGCGGACGGGTGAGTAACACGTGGGTAA } \\
\text { CCTGCCTGTAAGACTGGGATAACTCCGGGAAACCGGGGCTAATA } \\
\text { CCGGATGGTTGTTTGAACCGCATGGTTCAAACATAAAAGGTGGCT } \\
\text { TCGGCTACCACTTACAGATGGACCCGCGGCGCATTAGCTAGTTG } \\
\text { GTGAGGTAACGGCTCACCAAGGCAACGATGCGTAGCCGACCTGA } \\
\text { GAGGGTGATCGGCCACACTGGGACTGAGACACGGCCCAGACTC } \\
\text { CTACGGGAGGCAGCAGTAGGGAATTTCCGCAATGGACGAAAGT } \\
\text { CTGACGGAGCAACGCCGCGTGAGTGATGAAGGTTTCGGATCGT } \\
\text { AAAGCTCTGTTGTTAGGGAGACAAGTACCGTCGATAGGGC } \\
\text { GGTACCTTGACGGTACCTAACCAGAAAGCACGGCTAACTACGT } \\
\text { GCCAGCAGCCGCGGTAATACGTAGGTGGCAAGCGTTTCCGGA } \\
\text { ATTATTGGGCGTAAAGGGCTCGCAGGCGGTTCTTAAGTCTGAT } \\
\text { GTGAAAGCCCCCGGTCAACCGGGGAGGGTCATTGGAAACTGG } \\
\text { GGAACTTGAGTGCAGAAGAGGA }\end{array}$ & 623 & Bacillus subtilis & JF266596 \\
\hline
\end{tabular}


Table 2. Contd......

ACATGCAAGTCGAGCGGCAGCACAGGAGAGCTT-

GCTCTCTGGGTGGCGAGTGGCGGACGGGTGAGGAATACATCGG

AATCTACTCTGTCGTGGGGGATAACGTAGGGAAACTTACGCTAAT ACCGCATACGACCTACGGGTGAAAGCAGGGGACCTTCGGGCCT

TGCGCGATTGAATGAGCCGATGTCGGATTATCTAGTTGGCGGGG

TAAAGGCCCACCAAGGCGACGATCCGTAGCTGGTCTGAGAGGAT

HL GATCAGCCACACTGGAACTGAGACACGGTCCAGACTCCTACGGG AGGCAGCAGTGGGGAATATTGGACAATGGGCGCAAGCCTGATC CAGCCATACCGCGTGGGTGAAGAAGGCCTTCGGGTTGTAAAGCC CTTTTGTTGGGAAAGAAATCCAGCTGGCTAATACCCGGTTGGGAT GACGGTACCCAAAGAATAAGCACCGGCTAACTTCGTGCCAGCAG CCGCGGTAATACGAAGGGTGCAAGCGTTACTCGGAATTACTGGG CGTACAGCGTGCGTAGGTGGTCGTT
549

Stenotropho-

monas

maltophilla
GTCGAGCGGCAGCACGGGTACTTGTAC-

CTGGTGGCGAGCGGCGGACGGGTGAGTAATGCCTAGGAATCTG

CCTGGTAGTGGGGGATAACGCTCGGAAACGGACGCTAATACCG

CATACGTCCTACGGGAGAAAGCAGGGGACCTTCGGGCCTTGCG

CTATCAGATGAGCCTAGGTCGGATTAGCTAGTTGGTGAGGTAAT GGCTCACCAAGGCGACGATCCGTAACTGGTCTGAGAGGATGATC AGTCACACTGGAACTGAGACACGGTCCAGACTCCTACGGGAGGC AGCAGTGGGGAATATTGGACAATGGGCGAAAGCCTGATCCAGCC ATGCCGCGTGTGTGAAGAAGGTCTTCGGATTGTAAAGCACTTTAA GTTGGGAGGAAGGGCAGTTACCTAATACGTATCTGTTTTGACGTT ACCGACAGAATAAGCACCGGCTAACTCTGTGCCAGCAGCCGCG
Pseudomonas

sp.
JF266597

GTAATACAGAGGGTGCAAGCGTTAATCGGAATTACTGGGCGTAA AGCGCGCGTAGGTGGTTTGTTAAGTTGAATGTGAAATCCCCGGG CTCAACCTGGGAACTGCATCCAAAACTGGCAGGCTAGAGTATGG TAGAGGGTGGTGGAATTTCCTGTGTAGCGGTGAAATGCGTAGAT ATAGGAAGGAACACCAGTGGCGAAGGCGACCACCTGGACTGATA CTGACACT ed counterparts. However, a considerable difference in types of colonizing species was observed between the insects raised on artificial dietand the field collected ones.

As previously described in other lepidopterans (Broderick et al., 2004; Xiang et al., 2006; Priya et al., 2012), the current study has also found Enterococcus in abundance when compared to rest of the phylotypes. The presence of Enterococcus in the gut benefits the host by reducing the gut $\mathrm{pH}$ thereby providing alkaline conditions that have a role in toxin effects (Wilson and Benoit, 1993). It was also identified that some of the gut microflora are involved in the degradation of polycyclic aromatic hydrocarbons (Lei et al., 2004) and insecticides (Hao et al., 2002). Other factors that influence the microbial diversity of the insect gut are host plant type and the host plant's geographical location. Therefore, artificial diet can therefore be considered a poor diet compared to field insects' diet which ultimately influ-

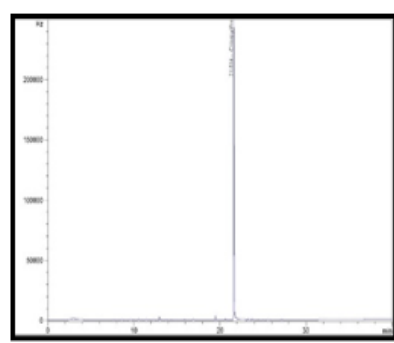

A

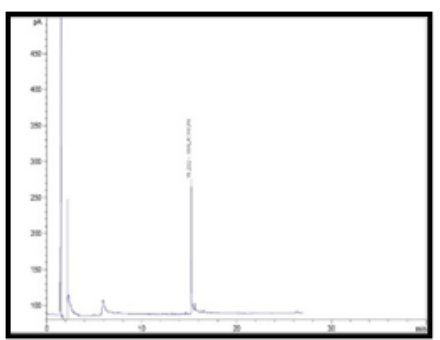

$\mathrm{B}$
Fig. 5. GC analysis of MSM with Chloropyriphos and Malathion, A- Chlorpyriphos B-Malathion ences the gut microflora diversity. As mentioned earlier, crop leaf surface influences the gut bacterial flora of Helicoverpa larvae. The phyllosphere bacteria offers functional resistance to its host plant and influences the gut bacterial community of the insect larva feeding on it (Rajendran et al. 2007). Further analysis of these systems may identify as to what other factors contribute to the significant variation in gut bacteria among larvae from different crops from different locations.

In the present study,eleven gut bacterial isolates from the gut of larvae of the insecticide resistant field and susceptible lab populations of $H$. armigera were tested for their growth on minimal salt media with chlorpyriphos, cypermethrin, malathion, quinalphos, and triazophos along with the control MSM without insecticides. The result analysis reveals that the bacterial isolates Rhodococcussp. and Enterococcus casseliflavus from gut of the field populations of $H$. armigera were able grow on an MSM medium with chlorpyriphos

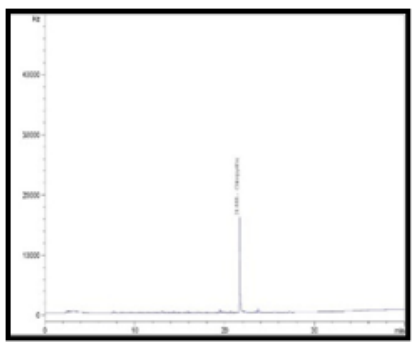

A

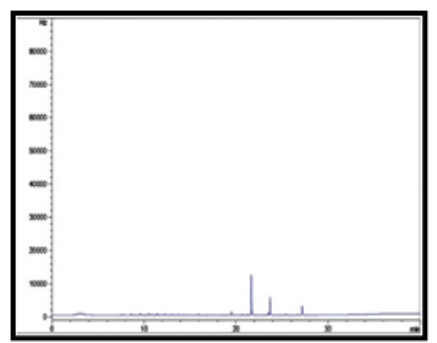

B
Fig. 6. GC analysis of MSM with Chloropyriphos and bacterial isolate HT3, A- Chlorpyriphos B-Control. 
Table 3. Growth of bacterial isolates on MSM medium with insecticides from the gut of Helicoverpa armigera.

\begin{tabular}{|c|c|c|c|c|c|c|c|}
\hline $\begin{array}{l}\text { Bacteri- } \\
\text { al Iso- } \\
\text { lates }\end{array}$ & Isolate Name & MSM & $\begin{array}{l}\text { MSM + } \\
\text { Chlorpyriphos }\end{array}$ & $\begin{array}{l}\text { MSM + Cyper- } \\
\text { methrin }\end{array}$ & $\begin{array}{l}\text { MSM + } \\
\text { Malathion }\end{array}$ & $\begin{array}{l}\text { MSM + } \\
\text { Qui- } \\
\text { nalphos }\end{array}$ & $\begin{array}{l}\text { MSM + } \\
\text { Triazo- } \\
\text { phos }\end{array}$ \\
\hline $\mathrm{CL1}$ & Bacillus pumillis & - & - & - & - & - & - \\
\hline CL2 & $\begin{array}{l}\text { Enterococcus } \\
\text { casseliflavus }\end{array}$ & -- & ++ & - & + & -- & - \\
\hline CL3 & Bacillus subtilis & - & - & - & - & - & - \\
\hline CL4 & Rhodococcus sp. & - & ++ & - & - & - & - \\
\hline CL5 & Pseudomonas sp. & - & - & - & - & - & - \\
\hline CL6 & Staphylococcus sp. & - & - & - & - & - & - \\
\hline CL7 & $\begin{array}{l}\text { Pseudomonas } \\
\text { aeruginosa }\end{array}$ & - & - & - & - & - & - \\
\hline HL1 & Proteus vulgaris & - & - & - & - & - & - \\
\hline $\mathrm{HL} 2$ & $\begin{array}{l}\text { Cellulosimicrobium } \\
\text { cellulans }\end{array}$ & - & - & - & - & - & - \\
\hline HL3 & Klebsiella oxytoca & - & - & - & - & - & - \\
\hline HL4 & Bacillus subtilis & - & - & - & - & - & - \\
\hline HL5 & $\begin{array}{l}\text { Stenotrophomonas } \\
\text { maltophilla }\end{array}$ & - & - & - & - & - & - \\
\hline HL6 & Pseudomonas sp. & - & - & - & - & - & - \\
\hline
\end{tabular}

$\left(\mathrm{C}_{22} \mathrm{H}_{19} \mathrm{Cl}_{2} \mathrm{NO}_{3}\right)$ and malathion $\left(\mathrm{C}_{10} \mathrm{H}_{19} \mathrm{O}_{6} \mathrm{PS}\right.$ ). From the analysis of the Gas Chromatography, the isolate CL4 (Enterococcus sp.) was able to utilize $43.9 \%$ of chlorpyriphos and isolate CL2 (Enterococcus casseliflavus) was able to utilize $26 \%$ of chlorpyriphos and $57.1 \%$ of malathion in MSM broth cultures with comparison with the respective control cultures. This indicates that these bacteria can utilize the insecticides as carbon source and why these two bacteria can utilize chlorpyriphos and malathion and why not other insecticides is not clear until now and further studies have to be done in this line of research. Earlier reports have indicated the role of different species of Enterobacteriacae in degradation of organophophorous insecticides like chlorpyriphos (Singh et al., 2004), phosphates (Lee et al., 1992) and glyphosates (Dick and Quinn, 1995). Carboxylesterases isolated from $H$. armigera play a role in pyrethroids detoxification (Bai et al., 2019). $\mathrm{H}$. armigera larva fed with laccasses from Yersinia enterocolitica showed significant expression of enzymes and proteins for xenobiotic degradation (Ahlawat et al., 2020). Thakur et al. (2005) showed that the bacterial isolates from the whole gut of the rice hispa, Dicladispa armigera (Olivler), belonging to genera Bacillus, Proteus, Micrococcus, Pseudomonas and Klebsiella were resistant to $1000 \mathrm{ppm}$ endosulfan and to some extent chlorpyriphos and quinalphos. The GLC analysis showed that the isolated gut bacteria had the potential to degrade endosulfan. This work probably can be a support to the current research to show that insect gut bacteria are playing a role in insecticide resistance. The study shows the potential of symbiotic bacteria in imparting insecticide resistance to insect hosts. As organ- ic phosphorous compounds are used so widely in agriculture for pest control, symbiont detoxification could represent a rapid and previously unappreciated mechanism for insecticide resistance in insects (Whalon et al., 2008). Given the general detoxification ability of microbes and their ability to evolve quickly, they could provide a potent means for rapid acquisition of insecticide resistance in hosts. Many insects harbor a robust complement of prokaryotes in their alimentary canals,

Table 4. Colony forming units of the bacterial isolates (CL4 and CL2) on nutrient agar.

\begin{tabular}{ll}
\hline MSM broth culture & CFU/ml \\
\hline Control & 00 \\
MSM + CL4 & $3 \times 10^{-4}$ \\
MSM + CL4 + Chlorpyriphos & $7 \times 10^{-4}$ \\
MSM + CL2 & $1 \times 10^{-4}$ \\
MSM + CL2 + Chlorpyriphos & $3 \times 10^{-4}$ \\
MSM + CL2 + Malathion & $2 \times 10^{-4}$ \\
\hline
\end{tabular}

Table 5. Concentration of insecticides in MSM broth cultures with bacterial isolates CL4 and CL2 analysed by GC-ECD.

\begin{tabular}{lll}
\hline $\begin{array}{l}\text { MSM broth } \\
\text { culture }\end{array}$ & $\begin{array}{l}\text { Chlorpyriphos } \\
\text { Conc. }(\mu \mathrm{g} / \mathrm{ml})\end{array}$ & $\begin{array}{l}\text { Malathion } \\
\text { Conc. }(\boldsymbol{\mu g} / \mathrm{ml})\end{array}$ \\
\hline Control & 00 & 00 \\
MSM & 38.29 & 112.27 \\
MSM + CL4 & 16.81 & --- \\
MSM + CL2 & 10.05 & 64.13 \\
\hline
\end{tabular}




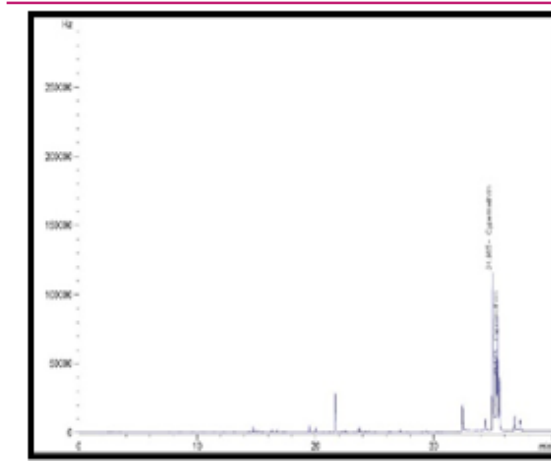

A

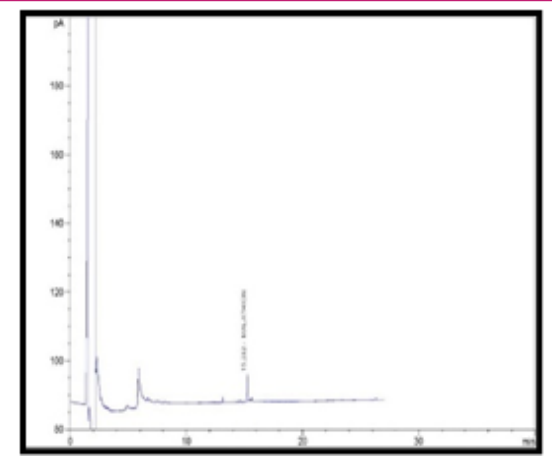

B

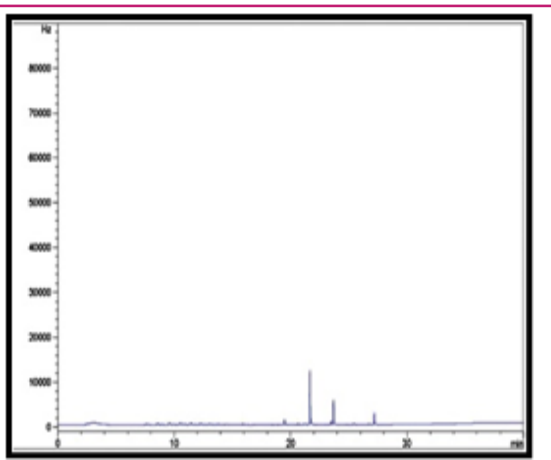

$\mathrm{C}$

Fig. 7. GC analysis of MSM with chloropyriphos, malathion with bacterial isolate CL2 A- Chlorpyriphos B-Malathion C - Control.

which facilitate nutrient availability, utilization and detoxification of environmental toxins, degradation of insect diet components (Williams and Roans, 2006; Hayashi et al., 2007). Earlier reports have also shown that the gut bacterial isolates of other insect species play an important role in insect growth and development. Jing et al., (2020) described the roles of gut bacteria as essential nutrient provisioning, digestion and detoxification.Bacillus thuringiensis isolated from the gut region of $H$. armigera play a major role in inducing pathogenicity of $\mathrm{Bt}$ toxin in the host (Regode et al., 2016). Carol et al., (2003) reported that the gut bacterial isolate Enterobacter agglomerans from the apple maggot fly was able to degrade and detoxifiy Dihydrochalcone Phloridzin, a plant derived compound toxic to Rhagoletis pomonella (Walsh) (Diptera: Tephritidae). Vesta et al.,(2006) reported that bark beetles Ips typographus (Coleoptera: Scolytidae) fed on conifers which produce myrcene (MR), among some other defensive compounds, six bacterial isolates from the gut of the bark beetles were most resistant to the bactericidal compound. 16S rRNA analysis of these bacteria showed that they are related to Enterobacteriaceae.Studies conducted by Genta et al. (2006) on antibiotic-treated and non-treated larvae of Tenebrio molitor suggested that microbial products play subtle roles in the life of the insect, digestion of refractory food, detoxification of secondary plant compounds and modify the volatile profiles of the insect host. Visotto et al., (2009) treated the bacterial colonies isolated from the gut homogenate of velvetbean caterpillar, Anticarsia gemmatalis with tetracycline. They found that the antibiotic was sensitive to the bacteria and inhibited the bacterial proteases. Their results suggested that gut bacteria may significantly contribute to lipid- and mainly protein-digestion in velvetbean caterpillars. Anand et al. (2010) reported that the bacterial species Proteus vulgaris, Klebsiella pneumoniae, Escherichia coli, Citrobacter freundii, Serratia liquefaciens, Enterobacter sp., Pseudomonas fluorescens, P. aeruginosa, Aeromonas sp., and Erwinia sp. isolated from the gut of
Bombyx mori L. were able to produce digestive enzymes that degrade the carbohydrates present in the mulberry leaves. In the current study, gut bacteria from laboratory populations of $H$. armigera and laboratory and field population of $T$. chilonis could not utilize the insecticides. It can be justified that they are not exposed to insecticides, whereas in the field populations one of the total isolated bacteria could utilize the insecticides for their growth. This might be because field populations are under constant stress of insecticides, which might induce the bacteria to produce enzymes to degrade and detoxify them. In field populations, only one per cent of the total bacterial isolates were able to utilize the insecticides and a possible explanation may be that microorganisms need an adaptation period to produce the necessary degradative enzymes (Jilani and Khan, 2004).

\section{Conclusion}

Enterococcus casseliflavus and Rhodococcus sp isolated from the gut region of $H$. armigera were able to grow in the presence of selected insecticides. Concluding from the current study results, it can be stated that gut bacteria in insecticide-resistant field populations of $H$. armigera play a significant role in insecticide resistance of the host. Understanding the insect gut microbial diversity, their functional roles in insect growth and development would offer crucial information for designing future pest management strategies.

\section{ACKNOWLEDGEMENTS}

The authors thank The Director of National Bureau of Agriculturally Important Insect Resources (NBAIIR), Indian Council of Agricultural Research, Bangalore for providing necessary facilities and guidance and laboratory facilities to carry out current research work.

\section{Conflict of interest}

The authors declare that they have no conflict of interest. 


\section{REFERENCES}

1. Anand, A.A.P., Vennison, S.J., Sankar, S.G., Prabhu, D.I.G., Vasan, P.T., Raghuraman, T., Geoffrey, C.J. \& Vendan, S.E. (2010). Isolation and characterization of bacteria from the gut of Bombyx mori that degrade cellulose, xylan, pectin and starch and their impact on digestion. Journal of Insect Science.10, 107-112.DOI: 10.1673/ 031.010.10701

2. Ahlawat, S., Singh, D., Yadav, A., Singh, A.K., Virdi, J. S., \& Sharma, K.K. (2020). Proteomic analysis reveals the damaging role of low redox laccase from Yersinia enterocolitica strain 8081 in the midgut of Helicoverpa armigera. Biotechnology letters, 42, 2189-2210. DOI: 10.1007/ s10529-020-02925-x

3. Bai, L.S., Zhao, C.X., Xu, J.J., Feng, C., Li, Y.Q., Dong, Y. L. \& Ma, Zhi-qing (2019). Identification and biochemical characterization of carboxylesterase $001 \mathrm{G}$ associated with insecticide detoxification in Helicoverpa armigera. Pest. Biochem. Physiol. 157, 69-79. DOI: 10.1016/j.pestbp.20 19.03.009

4. Broderick, N.A., Raffa, K.F., Goodman, R.M \& Handelsman, J. (2004). Census of bacterial community of gypsy moth larval mid gut by using culturing and culture independent methods. Applied Environmental Microbiology. 70, 290-300.DOI: 10.1128/AEM.70.1.293-300.2004

5. Carol, R.L., Sarah, E.P \& Ronald, J.P. (2003). Degradation and detoxification of the dihydrochalcone phloridzin by Enterobacter agglomerans, a bacterium associated with the apple pest, Rhagoletis pomonella (Walsh) (Diptera: Tephritidae. Environmental Entomology. 32, 953962.DOI: 10.1603/0046-225X-32.5.953

6. Dar, M.A., Shaikh, A.F., Pawar, K.D., Xie, R., Sun, J., Kandasamy, S., \&Pandit, R.S. (2021). Evaluation of cellulose degrading bacteria isolated from the gut-system of cotton bollworm, Helicoverpa armigera and their potential values in biomass conversion. PeerJ 9: e11254. DOI: 10.7717/peerj.11254

7. Dar, M.A., Shaikh, A.A., Pawar, K.D., \& Pandit, R.S. (2018). Exploring the gut of Helicoverpa armigera for cellulose degrading bacteria and evaluation of a potential strain for lignocellulosic biomass deconstruction. Process Biochemistry. DOI: 10.1016/j.procbio.2018.08.001

8. Dick, R.E., Quinn, J.P. (1995). Glyphosate-degrading isolates from environmental samples: occurrence and pathways of degradation. Applied Microbial Biocontrol. 43 (8): 545-550.DOI: $10.1007 / \mathrm{BF} 00218464$

9. Dillon, R.J and Dillon, V.M. (2004). The gut bacteria of insects: non-pathogenic interactions. Annual Review of Entomology. 49, 71-92. DOI: 10.1146/annurev.e nto.49.061802.123416

10. Gavriel, S., Jurkevitch, E., Gazit, Y. \& Yuval, B. (2010). Bacterially enriched diet improves sexual performance of sterile male Mediterranean fruit flies. Journal of Applied Entomology. 10, 439-444. DOI: 10.1111/j.1439-0418.201 0.01605.x

11. Gebbardi, K., Schimana, J., Muller, J., Krantal, P., Zeeck, A \& Vater, I. (2001). Screening for biologically active metabolites with endosymbiotic bacilli isolated from arthropods. FEMS Microbiology. 217, 199-205.DOI: 10.1111/ j.1574-6968.2002.tb11475.x

12. Genta, A.F., Dillon, R.J., Terra, R.W \& Ferreira, C. (2006).
Potential role for gut microbiota in cell wall digestion and glucoside detoxification in Tenebrio molitor larvae. Journal of Insect Physiology. 52, 593-601. DOI: 10.1016/j.jinsphy s.2006.02.007

13. Hao, O.J., Kim, M.H., Seagren, E.A \& Kim, H. (2002). Kinetics of phenols and chlorophenol utilization by Acinetobacter species. Chemosphere. 46, 797-807.DOI: 10.1016/S0045-6535(01)00182-5

14. Hayashi, A., Aoyagi, H., Yoshimura, T \& Hideo Tanaka, H. (2007). Development of novel method for screening microorganisms using symbiotic association between insect and intestinal microorganisms. Journal of Bioscience and Bioengineering. 103, 358-367. DOI: 10.1263/jbb.103.358

15. Hoffman, C.S \& Winston, F. (1987). A ten-minute DNA preparation from yeast efficiently releases autonomous plasmids for transformation of Escherichia coli. Gene. 57, 267-272. DOI: 10.1016/0378-1119(87)90131-4

16. Jilani, S and Khan, A.M. (2004). Isolation, characterization and growth response of pesticide degrading bacteria. Journal of Biological Science. 4, 15-20. DOI: 10.3923/ jbs.2004.15.20

17. Jing, T.Z., Qi, F.H. \& Wang, Z.Y. (2020). Most dominant roles of insect gut bacteria: digestion, detoxification, or essential nutrient provision? Microbiome 8, 38. DOI: 10.1186/s40168-020-00823-y

18. Kanekar, P.P., Bhadbhade, B.J., Deshpande, N.M \& Sarnaik, S.S. (2004). Biodegradation of Organophosphates. Biological Sciences. 70, 57-70

19. Kranthi, K.R., Jadhav, D., Wanjari, R., Kranthi, S. \& Russell, D. (2001). Pyrethroid resistance and mechanism of resistance in field strains of Helicoverpa armigera (Lepidoptera: Noctuidae). Journal of Economic Entomology. 94, 254-263. DOI: 10.1603/0022-0493-94.1.253

20. Lee, K.S., Metcalf, W.W. \&Wanner, B.L. (1992). Evidence for two phosphonate degradative pathways in Enterobacter aerogenes. Journal of Bacteriology. 174, 2501-2510. DOI: $10.1128 / j b .174 .8 .2501-2510.1992$

21. Lei, P., Nie, M.Q., Wen, X.M., Ge, B.Z. \&Zang, Z.J. (2004). Study of degradation characters of preponderant Flavobacterial strains in a mixture of anthracene, phenantherene and pyrene. Journal of Xi'an Jiaotong University.38, 657-658.

22. Mishra, P.K. and Tandon, S.M. (2003). Gut bacterial flora of Helicoverpa armigera (Hub.) (Lepidoptera: Noctuidae). Indian Journal of Microbiology. 43, 55-56.

23. Nagarkatti, S. and Satyaprakash, S. (1974). Rearing Helicoverpa armigera (Hubn.) on an artificial diet. Technical Bulletin Commonwealth Institute of Biological Control. 17, 169-173.

24. Paramasiva, I., Shouche, Y., Kulkarni, G. J., Krishnayya, P. V., Akbar, S. M., \& Sharma, H. C. (2014). Diversity in gut microflora of Helicoverpa armigera populations from different regions in relation to biological activity of Bacillus thuringiensis $\delta$-endotoxin Cry1Ac. Archives of Insect Biochemistry and Physiology, 87, 201-213. DOi: 10.1002/ arch.21190

25. Priya, N.G., Ojha, A., Kajla, M.K., Raj, A. \& Rajagopal, R. (2012). Host plant induced variation in gut bacteria of Helicoverpa armigera. PLoS One. 7, e30768.DOI: 10.1371/ journal.pone.0030768

26. Rajagopal, R., Sivakumar, S., Agrawal, N., Malhotra, P \& Bhatnagar, R.K. (2002). Silencing of midgut aminopepti- 
dase $\mathrm{N}$ of Spodoptera litura by dsRNA establishes its role as Bacillus thuringiensis toxin receptor. Journal of Biological Chemistry.277, 46849-46851. DOI: 10.1074/jbc.C200 523200

27. Rajendran, L., Samiyappan, R., Raguchander, T. \& Saravanakumar, D. (2007). Endophytic bacteria mediate plant resistance against cotton bollworm. Journal of Plant Interactions. 2, 1-10.DOI: 10.1080/17429140701420003

28. Rani, A., Sharma, A., Rajagopal, R., Adak, T.\& Bhatnagar, R.K. (2009). Bacterial diversity analysis of larvae and adult midgut micro-flora using culture-dependent and culture-independent methods in lab-reared and fieldcollected Anopheles stephensi-an Asian malarial vector. BMC Microbiology. 9, 96.DOI: 10.1186/1471-2180-9-96

29. Ranjith, M.T., Chellappan, M., Harish, E.R., Girija, D. \& Nazeem, P.A. (2016). Bacterial communities associated with the gut of tomato fruit borer, Helicoverpa armigera (Hubner) (Lepidoptera: Noctuidae) based on Illumina Next-Generation Sequencing. Journal of Asia-Pacific Entomology. 19, 333-340. DOI: 10.1016/j.aspen.20 16.03.007

30. Regode, V., Kuruba, S., Mohammad, A.S., \& Sharma, H.C. (2016). Isolation and characterization of gut bacterial proteases involved in inducing pathogenicity of Bacillus thuringiensis toxin in cotton bollworm, Helicoverpa armigera. Frontiers in Microbiology, 7, 1567. DOI: 10.3389/ fmicb.2016.01567

31. Sambrook, J., Fritsch, E.F. \& Maniatis, T. (2001). Molecular Cloning, A Laboratory Manual, $3^{\text {rd }}$ edn (Cold Spring Harbor Laboratory, Cold Spring Harbor, NY).

32. Sharon, G., Segal, D., Ringo, J.M., Hefetz, A. \& Rosenberg, I.Z. (2010). Commensal bacteria play a role in mating preference of Drosophila melanogaster. Proceedings of National Academy of Sciences. 107, 2005120056.DOI: 10.1073/pnas.1009906107

33. Shinde, A. A., Shaikh, F. K., Gadge, P. P., Padul, M. V., Govindwar, S. P., \& Kachole, M. S. (2017). Conserved nature of Helicoverpa armigera gut bacterial flora on different host plants and in vitro interactions with PI proteins advocates role in host digestive physiology. Journal of the Saudi Society of Agricultural Sciences. 18: 141149. DOI:10.1016/j.jssas.2017.03.004

34. Singh, K., Brajesh, K., Walker, A., Alum, J., Morgan, W \&
Wright, D.J. (2004). Biodegradation of chlorpyrifos by Enterobacter strain B-14 and its use in biodegradation of contaminated soils. Applied Environmental Microbiology. 70, 4855-4863.DOI: 10.1128/AEM.70.8.4855-4863.2004

35. Thakur, D., Bhuyan, M., Majumdar, S., Yadav, A., Hazarika, L.K., Harman, N., Baruah, A.A.L.H., \& Bora, T.C. (2005). Isolation, characterization, in-vitro antibiotic susceptibility and pesticide tolerance of gut bacteria from rice hispa, Dicladispa armigera (Olivier). Indian Journal of Microbiology. 45, 217-221.

36. Verma, K., Agarwal, M., Farooq, M., Misra, R.B \& Hans, R.K. (2006). Endosulfan degradation by a Rhodococcus strain isolated from the earthworm gut. Ecotoxicology and Environmental Safety. 64, 377-381.DOI: 10.1016/j.ecoe nv.2005.05.014

37. Vesta, S.A., Sandra, R \& Virmantas, S. (2006). Myrcene resistant bacteria isolated from the gut of phytophagous insects Ips typographus. Ekologia. 4, 1-6.

38. Visotto, L.E., Oliveira, M.G.A., Guedes, R.N.C., Ribon, A.O.B \& Good-God, P.I.V. (2009). Contribution of gut bacteria to digestion and development of the velvetbean caterpillar, Anticarsia gemmatalis. Journal of Insect Physiology. 55, 185-191.DOI: 10.1016/j.jinsphys.2008.10.017

39. Whalon, M.E., Mota-Sanchez, D. \& Hollingsworth, R. (2008). Global Pesticide Resistance in Arthropods. (CAB International, Oxfordshire, UK).

40. Wilson, G.R. and Benoit, T.G. (1993). Alkaline pH activated Bacillus thuringiensis spores. Journal of Invertebrate Pathology. 62, 87-89.DOI: 10.1006/jipa.1993.1079

41. Xiang, H., Wei, G. F., Jia, S., Huang, J. \& Miao, X.X. (2006). Microbial communities in the larval midgut of laboratory and field populations of cotton bollworm (Helicoverpa armigera). Canadian Journal of Microbiology. 52, 1085-1092.DOI: 10.1139/w06-064

42. Yang, X., Xu, P., Yuan, H., Graham, R.I., Wilson, K., \& $\mathrm{Wu}, \mathrm{K}$. (2019). Discovery and characterization of a novel picorna-like RNA virus in the cotton bollworm Helicoverpa armigera. Journal of Invertebrate Pathology, 160, 1-7. DOI: 10.1016/j.jip.2018.11.003

43. Yuan, H., Xu, P., Yang, X., Graham, R.I., Wilson, K., \& Wu, K. (2017). Characterization of a novel member of genus Iflavirus in Helicoverpa armigera. Journal of Invertebrate Pathology, 144, 65-73. DOI:10.1016/j.jip.20 17.01.011 